\title{
Corporate Governance Mechanism on Tunneling Incentive and Financial Distress and Their Impact on Corporate Turnaround (Study on Manufacture Companies in Indonesia Stock Exchange on 2013-2018)
}

\author{
Eneng Sugihyanty ${ }^{1 *}$, Tri Widyastuti ${ }^{2}$, Apollo Daito ${ }^{3}$, Widarto Rachbini ${ }^{4}$ \\ ${ }^{1}$ Building Management Kantor Taman A9 \\ ${ }^{2}$ Universitas Bhayangkara \\ ${ }^{3}$ Universitas Mercu Buana \\ ${ }^{4}$ Universitas Pancasila
}

*Corresponding Author: Eneng Sugihyanty, Building Management Kantor Taman A9, Indonesia

\begin{abstract}
This study analyzes and establishes the effect of corporate governance on tunneling incentive and financial distress and their impact on the corporate turnaround on manufacturing companies listed in Indonesia Stock Exchange from 2013 to 2018. Data obtained from Statistics IDX and BEI (Indonesia Stock Exchange) with the samples consist of 32 companies.

The research results indicate that direct effects boards of commissioners influence financial distress, independent commissioner influence tunneling incentive, and financial distress influence corporate turnaround. However, independent commissioners, boards of commissioners, institutional ownership, and tunneling incentive do not affect corporate turnaround. Boards of commissioners and institutional ownership variables do not affect tunneling incentive. Furthermore, independent commissioners and institutional ownership do not affect financial distress. Other results of the research indicate that indirect effects tunneling incentive and financial distress can not function as an intervening variable in the effect of corporate governance on the corporate turnaround.
\end{abstract}

Keywords: Turnaround, Tunneling Incentive, Financial Distress, Mechanism of Corporate Governance

\section{INTRODUCTION}

The economic crisis was caused by the unsuccessful implementation of corporate governance stemming from a weak legal framework system, inconsistent accounting and auditing standards, ineffective supervision of the board of commissioners, poor banking practices, and consideration of minority shareholders' rights. The application of the principle of weak corporate governance is one of the leading causes of economic insecurity, giving rise to adverse economic conditions and the long process of economic recovery in Asian countries such as Indonesia. Agency theory is the background of the issue of corporate governance where agency problems arise when ownership management is separate from the company. The board of commissioners and directors act as agents within the company and are given authority to manage a company's operations and make decisions. Based on the authority possessed, the manager can act unfavorably for the interests of the owner due to differences in interests.

Governance is a system that controls and regulates companies to create added value for those who have an interest. Parties who have an interest also have the right to obtain information and disclose reports transparently, accountability, responsibility, independence, and fairness of all information on company performance. If an error occurs in the implementation of company management, it will lead to bankruptcy (financial distress), then the party most responsible is management.

The financial appearance of the company is reflected by the full financial statements for a specified period. The report used in assessing the company's financial position consists of a Financial Position Report, Profit and Loss, Cash Flow, and a Capital Change Report. Financial distress is a condition of decline in corporate financial performance in large or small companies, which can be felt by all 
business and industrial sectors (Schuppe, 2005). In general, external parties that predict bankruptcy of a company are auditors, researchers, creditors, company owners, the government, and investors. The external parties will usually see distress signals such as: bills from banks, product quality problems, delivery delays, and others. With the analysis of financial distress on the company and the existence of other explanatory variables, namely, the opinion given by the auditor is presented in the financial statements, and independent commissioners on the audit committee are expected to have a significant enough role in identifying a company that is experiencing financial difficulties.

Financial distress occurs on an ongoing basis if not followed by anticipation from management. Companies that are experiencing financial distress are expected to be able to improve their performance. The ability of a company that experiences financial distress and can improve its performance after the period is called corporate turnaround. The corporate turnaround condition is manifested in the overall integrated activities, both from internal resource factors, corporate strategy, and the company's environment. Research on turnaround for companies experiencing financial distress has been conducted by Francis and Desai (2005); Smith and Graves (2005), in Indonesia has been studied by Bodroastuti (2009) and Widyasaputri (2012).

A company's cycles and declining financial performance are caused by external and internal factors (Francis and Desai, 2005). Research on turnaround and financial distress is very interrelated; this is due to the company's success of turnaround, which is determined by the company's response to address the problems that have brought the company into financial distress. Companies in financial distress will undertake the turnaround process to improve financial performance (Smith and Graves, 2005). The earlier response of management in analyzing financial distress, then acting actively to detect financial distress, and implementing an appropriate turnaround strategy, will control these conditions (Schuppe, 2005).

Tunneling is the behavior of the majority shareholders who transfer the company's wealth for personal gain, but minority shareholders bear the costs incurred (SU Dongwei and Xiong Jiacai, 2013). The owner of the company sells his assets cheaper than the cost of production, to affiliated companies in countries with lower tax rates, causing losses to the company. Companies that lose money will avoid paying taxes and will not distribute dividends. Even if the company makes a small profit, the dividend distribution will prioritize the majority shareholder, while here, the minority shareholders will suffer losses. It was concluded that tunneling incentive are incentives obtained from the majority shareholder's transfer of company assets and profits, but the minority shareholders must bear the costs.

Tunneling occurs in companies but is challenging to detect, and this is due to a lack of law enforcement, inadequate quality disclosure, and weak governance systems. If it is not controlled by tunneling, it can cause losses to companies, minority shareholders, even society and the state. The ownership structure in manufacturing companies in Indonesia causes almost all companies to conduct related party transactions. The purpose of related transactions is to improve group welfare and efficiency. Misuse of related party transactions is a challenge for the integrity of capital market developments and becomes a governance reform.

A successful turnaround is a complex combination process that includes internal resources, environmental factors, and relevant strategies used in various stages to obtain improved financial performance. Companies need effective strategies for turnaround success or achieve recovery (Schendel and Patton, 1976). The response that must be taken by the company in improving the company's internal control, changing its top management, or reducing the scale and scope of operations. Companies need to know the cause of the decline precisely and quickly so they can choose an effective strategy. Bruton et. al, (2003) explained that operational solutions must be used in overcoming internal and operational problems of the company, while in overcoming external and strategic problems, strategic strategies must be used. Among them, reposition the company using the right way to arrange assets. While operating solutions include retrenchments such as asset reduction, sales increase, and cost reduction.

The problems in this study are limited by variables that affect turnaround according to problem identification. In this study, corporate governance mechanism are limited to only Independent Commissioners, Board of Commissioners, and Institutional Ownership and Tunneling Incentive, 
Financial Distress. This study uses manufacturing companies as research objects listed on the Indonesia Stock Exchange and will look for a span of 6 years from 2013 to 2018 in conducting turnarounds. Manufacturing companies consist of various industrial sub-sectors so that the overall capital market reaction is reflected, and most manufacturing companies produce the products they need. Manufacturing companies have shares that can survive in conditions of economic crisis when compared with other companies.

Based on the problem's identification and limitation, the research problem is formulated as follows:

1. Corporate governance mechanism affect tunneling incentive.

2. Corporate governance mechanism affect financial distress.

3. Corporate governance mechanism affect turnaround.

4. Tunneling incentive affect turnaround.

5. Financial distress affects turnaround.

6. Corporate governance mechanism affect turnaround through tunneling incentive.

7. Corporate governance mechanism influences turnaround through financial distress.

\section{LITERATURE REVIEW}

\subsection{Turnaround}

Turnaround is a term used to process a company in an unhealthy condition. Turnaround here is used to explain the strategies used by companies in making a change to deal with many problems but still have adequate time and resources. Thus, the company's condition is in a crisis stage, but it can still move, especially in improving competitiveness and efficiency. Corporate turnaround is an effort to reverse the company's direction due to the decline in performance to increase the company's financial performance. Yuliana and Dosugi (2013) stated that turnaround is an effort to get out of failures experienced by management in enlarging the company so that the company's future is bright and can come out of a prolonged crisis. Management and owners will try to turn the company around. Turnaround success is a complex process of internal resources, environmental factors, and corporate strategies combined in various stages of performance degradation to produce the best financial performance (Francis and Desai, 2005).

Francis and Desai (2005) describe 4 stages of conditions during a declining financial performance and company turnaround cycle. The first stage, the company's condition at the peak of financial performance and the year before its decline. In the second stage, the company experienced a decline (decline) and financial distress. In the third stage, companies make efficiency in the form of reducing costs and assets. The fourth stage, the overall turnaround performance period, which shows a company managed to achieve turnaround or did not succeed in turnaround. A company in a state of financial difficulties and successful recovery, then it is a success of turnaround.

\subsection{Tunneling Incentive}

The term tunneling was initially used to describe the actions of a majority shareholder in the Czech Republic in the takeover of minority shareholders, such as the transfer of assets through an underground tunnel (tunnel). Described in the ownership structure are the types of agency conflicts that can occur. There are two ownership structures, namely concentrated ownership, and scattered ownership structures. In a dispersed ownership structure, non-controlling shareholders are weak in the company's operational oversight and are not involved in making company policies or decisions. In this case, the manager will put his interests before the interests of shareholders.

According to Mitton (2002), tunneling is:

"Tunneling comes in two forms. First, a controlling shareholder can simply transfer resources from the firm for its benefits through self-dealing transactions. Such transactions include outright theft or fraud, which are illegal everywhere through often go undetected or unfunished, but also asset sales, contracts such as transfer pricing advantages to the controlling shareholders, excessive executives. "

Tunneling transactions occur in parent companies in China, through credit by subsidiaries in parent companies (Jiang et al., 2005). At the same time, business transactions at companies in India use non- 
ordinary compared to trade transactions in tunneling. The study of Aharony et al. (2009) explains earnings management before the IPO process is motivated by tunneling behavior. Credit transactions after IPOs to related parties are used as a tool to transfer assets. Tunneling behavior is a form of intervention from the majority of shareholders who have specific goals in obtaining personal gain. Tunneling transactions can reduce financial performance and the value of companies that have been tunneled.

\subsection{Financial Distress}

Financial distress is a company's financial condition that is in trouble, a crisis experienced by a company before it goes bankrupt. A company's financial difficulties, in general, experience a decline in profits, fixed assets, and decreased growth, and inventory levels are relatively down (Kahya, Theodossiou, 1999).

According to Debarshi Bhattacharyya (2012),

Distress means acute financial hardship/crisis. Corporate distress/sickness means such a firm's situation when it is unable to meet its debt. When the value of a company's total assets is insufficient to discharge its total external liabilities, the company can be said a 'distress company.'

This means that distress is a condition of crisis or financial difficulties that are very acute. The company is experiencing pain or in a state of difficulty, meaning that its condition is the inability to pay debts. The total value of the company's assets is not sufficient to pay the total obligations/debts to external parties, and then the company will experience difficulties. Each company's strategy is different in carrying out the company's operational activities; of course, it is expected to be able to generate revenue for the company. Financial distress is not only felt by company management but by stakeholders, shareholders, creditors, and suppliers, so that much impact arises in this condition. Companies must strive to avoid financial difficulties in worse conditions.

Financial distress indicates a decline in the company's financial condition before the liquidation or bankruptcy (Plat and Plat, 2002). If the handling of financial distress is not proper, then the company will experience bankruptcy or liquidation. Bankruptcy also means financial failure (economic failure) and economic failure (economic failure). Financial distress is also defined as the company's inability to settle financial obligations that are past due. (Beaver et al., 2011).

The company's financial distress occurs due to various factors, both external and internal factors. Internal factors of the company where the company does not have proper management and are responsive in dealing with problems. In some industries, the condition of financial distress is influenced by external factors. Companies that experience an economic crisis are seen as unfavorable because it has a significant impact on investors, stakeholders, and corporate creditors. After the company passes the financial distress condition or succeeds in making a recovery of turnaround, the trust of investors, suppliers, and creditors will return because the company's performance is considered to be increasing or good.

\subsection{Corporate Governance}

Corporate governance (corporate governance) is a series of processes, policies, habits, rules, and institutions that affect the management, control, and direction of a corporation or company. Corporate governance is a subject that has many aspects. One of the main topics of corporate governance is related to the issue of responsibility and accountability. In this case, the mechanism and implementation to ensure proper behavior and protect the interests of shareholders. In addition to responsibility and accountability, economic efficiency is another focus that states that governance must be aimed at optimizing financial results, focusing on welfare for shareholders.

The corporate governance system is divided into two parts: internal governance mechanisms and external mechanisms that are diverse based on a particular environment (Charlie Weir et al., 2000). Internal governance mechanism indicators consist of the number of boards of commissioners, the proportion of independent boards of commissioners, and the number of directors, while the indicators of external governance mechanisms consist of institutional ownership (S. Beiner et al., 2003). If the two mechanisms work together, the corporate governance system can motivate managers to maximize value for shareholders (Alexander and Matts, 2002). Previous research Hermalin and Weisbach 
(2003) and Allen and Gale (2000) confirmed that the number of board directors and the proportion of commissioners is an essential indicator of governance mechanisms because directors can ensure that managers follow the interests of the board. Corporate governance consists of the following elements, the proportion of independent commissioners, company ownership, and directors (Fitdini, 2009).

Corporate governance aims to increase added value for all interested parties (stakeholders). The implementation of governance can increase the company's value (size) by efforts to improve the company's financial performance and reduce the risk of the board of commissioners through policies that benefit themselves. In general, good corporate governance is a system that can increase investor confidence. Corporate governance includes the relationship between the stakeholders involved and the objectives of company management. Incorporate governance, the main parties involved are shareholders, directors, and management, including employees, customers, creditors, suppliers, government, and the community environment.

The basis for understanding corporate governance as a whole is agency theory. Agency is an agreement or contract between manager as agent and investor as principal, which often creates information asymmetry from agent to principal, which causes agency costs. Ownership structure also affects agency problems, seen from the size of shares owned by a person or institution of a company.

In this study, the mechanism of corporate governance is a set of rules or a system that regulates the relationship of corporate stakeholders related to the obligations and rights of these stakeholders. Thus the governance mechanism can be said as a system that controls and directs the company's performance to be carried out according to procedures and principles of governance in order to achieve the targets and objectives of the company and avoid fraudulent behavior and be able to produce timely and accountable reports for decision making so that the existence of corporate governance will be able to avoid tunneling behavior and financial distress conditions.

\section{RESEARCH METHODOLOGY}

This research was conducted on empirical testing of the model building developed in the previous discussion based on the proposed basic theoretical model, namely the variable of corporate governance mechanisms on shareholder behavior in transferring assets (tunneling incentive) and financial distress impact on the turnaround. The research conducted is a causal relationship analysis and exploratory analysis of causal relationships, the results of which are expected to strengthen a theory as a basis for thinking in problem-solving. This study empirically examines the variables that can influence the likelihood of turnaround success. The data used in this study are secondary in the form of financial statements from manufacturing companies listed on the Indonesia Stock Exchange and have been published. The time-series data used in the study is the period 2013-2018. This type of research is clear causality with a purposive sampling method, a method that uses specific criteria and limits to obtain samples that are consistent with the research objectives.

Manufacturing companies are the population used in this study, where these companies have been listed on the Indonesia Stock Exchange and published financial statements for the 2013-2018 fiscal year. The data used in this study is secondary data obtained from the Indonesia Stock Exchange data center (www.idx.co.id). Samples were obtained from populations that are manufacturing industry companies, and their shares are listed on the Indonesia Stock Exchange. Research period in 20132018.

The research model that the researcher developed is based on previous studies and theoretical development that illustrates the relationship between variables that researchers use, can be seen in the picture as follows:

\subsection{Research Framework}

The basis for understanding corporate governance as a whole is agency theory. Agency is an agreement or contract between manager as agent and investor as principal, which often creates information asymmetry from agent to principal, which causes agency costs. Ownership structure also Affects agency problems, seen from the size of shares owned by a person or institution of a company.

In this study, the mechanism of corporate governance is a set of rules or a system that regulates the relationships of corporate stakeholders related to the obligations and rights of these stakeholders. Thus 
the governance mechanism can be said as a system that controls and directs the company's performance to be carried out according to procedures and principles of governance in order to achieve the targets and objectives of the company and avoid fraudulent behavior and be able to produce timely and accountable reports for decision making so that the existence of corporate governance will be able to avoid tunneling behavior and financial distress conditions.

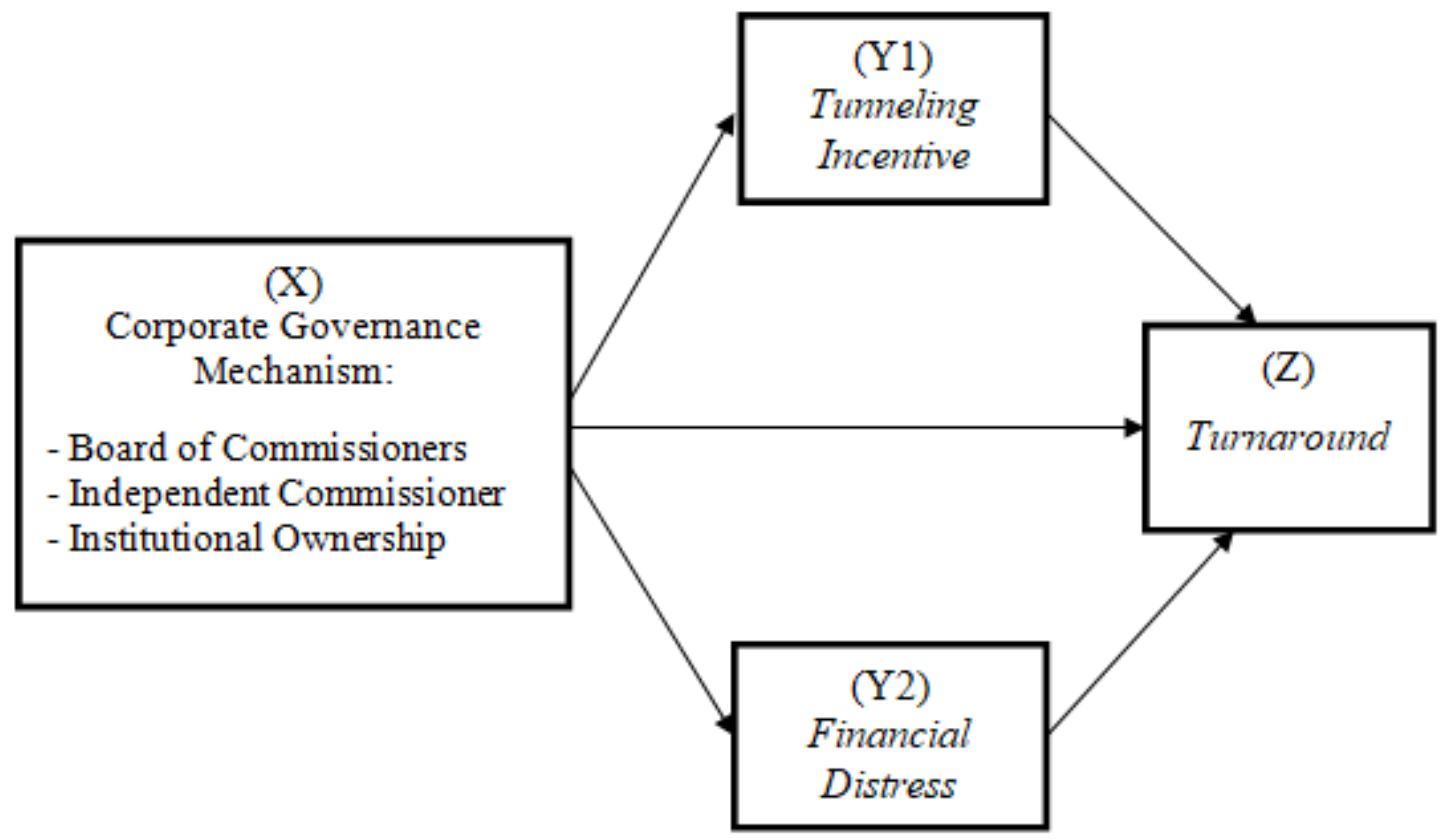

The hypothesis is the relationship between two or more variables in the formulation of propositions that can be tested empirically. Based on these descriptions, reviewing the literature, previous studies, and theoretical frameworks that have been prepared, the hypotheses proposed in this study are as follows:

H1: Corporate governance mechanism negatively affect tunneling incentive.

$\mathrm{H} 2$ : Corporate governance mechanism hurt financial distress.

H3: Corporate governance mechanism have a positive effect on the turnaround.

H4: Tunneling incentive negatively affect turnaround.

H5: Financial distress harms the turnaround.

H6: The mechanism of corporate governance has a positive effect on turnaround through tunneling incentive.

H7: The mechanism of corporate governance has a positive effect on turnaround through financial distress.

\section{ANALYSIS AND DisCUSSION}

\subsection{Descriptive Statistics}

Manufacturing companies listed on the Indonesia Stock Exchange during the observation period of 2013 to 2018, from the observations of the most dominant sector companies in this study, are plastic and packaging companies. The results showed that of the 32 sample companies during the study period of 2013 to 2018, the minimum or maximum turnaround value ranged from -2.34 to 1.63. The average value of -0.05 and the standard deviation of 0.301 . Description of tunneling incentive variables obtained an average of 0.26 , a minimum value of 0.00 , and a maximum of 0.96 . As for the standard deviation of 0.296 . Financial distress obtained a minimum value of -0.31 and a maximum of 192.57. For a standard deviation of 63,099 and an average of -6.84. The description of the board of commissioners variable from the research results obtained a maximum value of 7.00 people and a minimum of 2.00 people. With an average value of 4.31. Independent commissioners have a minimum value of 0.00 and a maximum of 0.667 . For the average value of an independent 
commissioner of 0.398 and a standard deviation of 0.135 . The research results description of institutional ownership variables obtained standard deviation values of 23.091 and an average of 66.64. With a minimum value of 0.00 and a maximum of 96.31. The standard deviation of institutional ownership of 23.091 is smaller than the average value of 66.64 .

\subsection{Analysis of Results}

\section{The goodness of Fit Test}

\section{The goodness of Fit Indices Model Test Results}

\begin{tabular}{|l|l|l|l|}
\hline $\begin{array}{l}\text { Goodness of Fit } \\
\text { (GOF) Index }\end{array}$ & Cut-off Value & $\begin{array}{l}\text { Estimated } \\
\text { Results }\end{array}$ & Information \\
\hline Chi-square & Expected to be Small & 0,355 & good fit \\
\hline CMIN/DF & $\leq 2,0$ & 0,36 & good fit \\
\hline Probability & $\geq 0,05$ & 0,551 & good fit \\
\hline RMSEA & $\leq 0,08$ & 0,000 & good fit \\
\hline GFI & $\geq 0,90$ & 0,999 & good fit \\
\hline TLI & $\geq 0,95$ & 1,318 & good fit \\
\hline AGFI & $\geq 0,90$ & 0,987 & good fit \\
\hline CFI & $\geq 0,95$ & 1,000 & good fit \\
\hline
\end{tabular}

Source: Data Processing Results

The Goodness of Fit Indices table concluded that the variables used in this study from the modified model fit with existing data; therefore, hypothesis testing can be used and continued. The results showed that the model used was acceptable. CMIN / DF value of 0.36 indicates a structural equation model is good. The RSMEA measurement index is between the expected value of $\leq 0.08,0.000$. Chisquare value of 0.355 is a relatively small value; the probability level is more than 0.05 , that is 0.551 , CFI value of 1,000 , and TLI value of 1.318 are accepted marginally. Based on several model feasibility tests, the model is feasible if at least one of the model feasibility test methods is met. In a study, researchers are not required to meet all the criteria of goodness of fit but depend on each researcher's judgment. From the model output results in the table for the model, suitability test criteria have met all the criteria of goodness of fit. Marginal value is the condition of the suitability of the measurement model under the criteria of perfect fit and incremental fit, but it can still be continued further analysis near the criteria of the goodness of fit.

\subsection{Hypothesis}

The estimated criteria for basic goodness of fit are met, then the next stage is the relationship between constructs in the study shown by the results of regression weights (Hair et al., 1998). To analyze the effect of corporate governance, tunneling incentive, and financial distress on a turnaround in manufacturing companies more clearly. Hypothesis testing is done by looking at the critical ratio (CR) contained in the AMOS output table regarding regression weights shown in the following table:

\section{Regression Weights}

Regression Weights: (Group number 1 - Default model)

\begin{tabular}{|l|l|l|l|l|l|l|l|}
\hline & & & Estimate & S.E. & C.R. & P & Label \\
\hline TUNNELING & $<---$ & COMMISSIONER & .003 & .013 & .197 & .844 & par_1 \\
\hline FINANCIAL & $<---$ & COMMISSIONER & -6.093 & 2.868 & -2.124 & .034 & par_2 \\
\hline TUNNELING & $<---$ & INDEN & -.494 & .156 & -3.173 & .002 & par_3 \\
\hline FINANCIAL & $<---$ & INDEN & 15.963 & 33.712 & .474 & .636 & par_4 \\
\hline TUNNELING & $<---$ & INST & .001 & .001 & .611 & .541 & par_5 \\
\hline FINANCIAL & $<---$ & INST & .191 & .203 & .941 & .347 & par_6 \\
\hline TURNAROUND & $<---$ & INDEN & -.093 & .163 & -.568 & .570 & par_7 \\
\hline TURNAROUND & $<---$ & COMMISSIONER & .003 & .014 & .216 & .829 & par_8 \\
\hline TURNAROUND & $<---$ & INST & .000 & .001 & .387 & .699 & par_9 \\
\hline TURNAROUND & $<---$ & TUNNELING & .100 & .074 & 1.349 & .177 & par_10 \\
\hline TURNAROUND & $<---$ & FINANCIAL & .001 & .000 & 2.767 & .006 & par_11 \\
\hline
\end{tabular}


Source: Data Processing Results

Based on the results of the analysis shows that directly the independent commissioner has an effect on tunneling with a $C R$ value of $-3,173(p=0.002<0.05)$ This shows the negative coefficient of the independent commissioner variable on tunneling incentive, meaning that the more independent commissioners, the tunneling incentive will getting smaller. The nature of the negative influence is significant, meaning that there is a negative influence between the independent commissioners on tunneling incentive. The results show that the average value for independent commissioners in manufacturing companies is $40 \%$; this shows that the percentage of independent commissioners is above $30 \%$ so that they can supervise the board of commissioners. Independent commissioners are members of the board of commissioners who are not affiliated with management, majority shareholders, other members of the board of commissioners, and are free in business relations or other relationships to affect their ability to act independently or act in the interests of the company. In contrast to previous research, this study uses the direct influence of independent commissioners on tunneling. Related party transactions can be used to transfer assets out of the company in meeting the interests of the controlling shareholder. There is a core motivation of the company in conducting particular relationship transactions: First, related transactions are used for commercial purposes. Second, related transactions are used for opportunistic purposes, namely earnings management (Jian and Wong, 2003; Aharony et al., 2009) and tunneling purposes (Cheung et al., 2009a; Cheung et al., 2009b, Cheung et al., 2006).

Second, directly the board of commissioners variable influences the financial distress, which has a CR value of $-2.124(\mathrm{p}=0.034<0.05)$; this means that the more the number of the board of commissioners, the financial distress condition decreases. The negative coefficient is significant, meaning that there is a negative influence between the board of commissioners on financial distress. Committees are generally formed by the board of commissioners in assisting the duties of the board of commissioners in carrying out their responsibilities and authorities. The board of commissioners plays a role in overseeing management behavior in the implementation of corporate governance. The size of the board of commissioners will have an impact on the company's financial condition. The more number of the board of commissioners, the supervisory function in the directors' policy will be able to run well and produce excellent performance, too, so that the company can avoid experiencing financial distress. This research contradicts the research conducted by Christina and Fajar (2008) and Arieny and Tarmizi (2012), which stated that the board of commissioners did not affect financial distress. However, in line with the results of research by Jansen (1993), Lipton and Lorsch (1992), Yenmark (1996) explains that the size of the board of commissioners influences financial distress.

Third, the financial distress variable directly influences turnaround by obtaining a CR value of 2.767 $(\mathrm{p}=0.006<0.05)$. This means that there is a positive influence between financial distress on the turnaround. The results of this study prove the positive influence between financial distress on turnaround, the size of the company size indicates how much effort the company has to get out of the distress it experiences, in order to be able to get out of their distress zone. A company that is experiencing financial distress has more ability to reorganize because it is triggered to be the best, and the company's condition will recover healthy; the company can carry out turnaround strategies. In overcoming financial distress, one of them needs to be efficient, reducing all kinds of financing and operating expenses. This helps distressed companies recover their turnaround. This study contrasts with the research conducted by Makgeta (2010), showing the results that the level of severity does not affect turnaround success. However, this research is in line with the study (Francis and Desai, 2005).

In contrast, independent commissioners, board of commissioners, institutional ownership and tunneling did not affect turnaround, each showing $\quad p=0.570, p=0.829, p=0.699$ and $p=0.177$, all $\mathrm{p}$ values greater than 0.05 . This study contradicts Joseph Murphy's (2008) study, which explains that corporate governance influences turnaround. According to Chiang and Lin (2007), explaining that the composition of the board of commissioners and electoral structure is a major component in corporate governance, and research is consistent with Joseph Murphy's (2008) research. The direct effect of other variables consisting of the board of commissioners with a value of $p=0.844$ and institutional ownership $\mathrm{p}=0.541$ so that it does not affect tunneling. This study is not consistent with previous studies of corporate governance and Institutional Investors influencing tunneling Qiao Liu, Zhou (Joe) Lu (2007), and Guohua J, Charles M. C. Lee, Heng Yue (2009). But in line with previous 
research Bertrand et al. (2002). Simultaneously, the results of independent testing commissioners and institutional ownership do not affect financial distress, because each p-value is greater than 0.05 , namely $\mathrm{p}=0.636$ and $\mathrm{p}=0.347$. The results of this study are consistent with Cinantya and Merkusiwati's research (2015), which explains that independent commissioners have no significant effect on financial distress and research by Widyasaputri (2012) and Bodroastuti (2009) who explain institutional ownership does not affect financial distress. But contrary to research by Daily and Dalton (1994) and Elloumi and Gueyie (2001).

The results of the analysis of the indirect effect between governance mechanisms on turnaround mediated by tunneling incentive and financial distress show that there is no indirect effect between governance mechanisms on turnaround mediated by tunneling incentive and financial distress. Judging from the results of turnaround calculations where the total coefficient is smaller than the linear coefficient between governance mechanisms and turnaround through tunneling incentive, that is $-0,619<-0.58$, and the total coefficient is smaller than the linear coefficient between governance mechanisms and turnaround through financial distress that is $9,932<9,971$. The results of this study do not affect because the board of commissioners and institutional ownership in manufacturing companies sampled are only formalities in meeting IPO standards so that institutional ownership cannot influence policy in corporate financial decision making. The policies taken are not appropriate and are not beneficial for controlling shareholders, and this causes a decline in company assets, and the condition of the company will become increasingly deteriorating. This study's results are not consistent with Joseph Murphy's (2008) study that explains governance mechanisms influence the turnaround.

\section{CONCLUSION AND SUgGeSTiONS}

\subsection{Conclusion}

Based on the results of the study, a series of data analysis and processing and discussion of the effects of governance, tunneling incentive and financial distress and their implications for a turnaround, several conclusions are drawn, namely:

1. Independent commissioners negatively affect tunneling incentive; the board of commissioners and institutional ownership do not affect tunneling incentive.

2. There is no influence between independent commissioners and institutional ownership on financial distress, while the board of commissioners negatively influences financial distress.

3. There is no influence between independent commissioners, the board of commissioners, and institutional ownership on the turnaround.

4. There is no influence between tunneling incentive on the corporate turnaround.

5. There is a significant favorable influence between financial distress on the corporate turnaround.

6. There is no influence of governance mechanisms on turnaround through tunneling incentive.

7. The mechanism of corporate governance does not affect turnaround through financial distress.

\subsection{Suggestions}

Based on the conclusions and results of data analysis that has been studied, the authors provide the following suggestions:

1. Company management is expected to detect bankruptcy early so that preventive actions can be taken. The bankruptcy prevention measure is the final act of salvage that can be done in margins or financial restructuring. Companies should analyze using the right strategies and decisions for the company's survival because good governance is an essential step in encouraging and building trust in better and long-term international investment flows.

2. Government agencies are interested in seeing early signs of bankruptcy so that actions need to be taken earlier. It can take steps or policies that are efficient and effective for all interested parties and are expected to be able to make policies or legal rules to protect minority shareholders' rights.

\section{REFERENCES}

[1] Aharony dan Loeb. 2009. Initial Public Offering, Accounting Choices, And Earning Management. Contemporary Accounting Research. Vol. 10, Issue 1. 
[2] Aharony, Jiwei Wang dan Yuan. 2010. Tunneling as An Incentive for Earnings Management During The IPO Process in China. Journal of Accounting and Public Policy. Vol. 29.

[3] Alexander dan Matts. 2002. Corporate Governance Mechanisms And Corporate Performance: Evidence From Finlandia. http://www.Shh.fi./ rosenberg/ goveranance.pdf

[4] Allen dan Douglas Gale. 2000. Corporate Governance and Competition. Dalam Vives, X. (Ed). Corporate Governance : Theoretical and Empirical Perspectives. Cambridge, United Kingdom: The Press Syndicate of the University of Cambridge.

[5] Bank Indonesia. Laporan Daftar Suku Bunga, diakses dari www.bi.go.id

[6] Beaver et al,. 2011. Financial Statment Analysi s and The Prediction of Financial Distress. Foundations and Trends in Accounting. Vol.V, Issue 2.

[7] einer et al,. 2003. Is Board size an Independent Corporate Governance Mechanism. www.ssrn.com.

[8] Bodroastuti. 2009. Pengaruh Struktur Corporate Governance terhadap Financial Distress. Jurnal Ilmu Ekonomi ASET. Vol.11, No. 2.

[9] Brutton, Ahlstrom dan Wan, J. 2003. Turnaround in East Asian firms, Evidence from Ethnic Overseas Chinese Communities. Strategic Management Journal. Vol. 24, Issue 6.

[10] Burton et al,. 2003. An Empirical Investigation of The Internationalshipof Organizational Culture, Managerial Values, and Organizational Citizenship Behavior. Dissertation. The Goerge Washington University.

[11] Charlie Weir et al,. 2000. An Empirical Analysis of the Impact of Corporate Governance Mechanisms on The Performance of UK Firm. http://papers.ssrn.com/sol3/papers.cfm?abstract_id=286440.

[12] Cheung, Raghavendra and Stouraitis. 2006. Tunneling, Propping and Expropriation, Evidence from Connected Party Transaction in Hongkong. Journal of Financial Economics. No. 82, p. 343-386.

[13] Cheung, Lihua Jing, Raghavendra and Stouratis. 2009a. Tunneling and Propping up, An Analysis of Related Party Transaction by Chinese Listed Company. Pasific Basin Finance Journal. No.17, p. 372-393.

[14] Cheung, Yuehua Qi, Raghavendra and Stouraitis. 2009b. Buy High, Sell Low, How Listed Firm Price Asset Transfer in Related Party Transaction. Journal of Banking and Finance. No. 33, p. 914-924.

[15] Christina dan Fajar Yuniarto. 2008. Mekanisme Corporate Governance Dalam Perusahaan yang Mengalami Permasalahan Keuangan. Jurnal Informasi, Perpajakan, Akuntansi dan Keuangan Publik, Vol. 3. No. 2. pp. 83-100.

[16] Cinantya, Merkusiwati. 2015. Pengaruh Corporate Governance, Financial Indicators, dan Ukuran Perusahaan pada Financial Distress. E-Jurnal Akuntansi Universitas Udayana. Vol.10, No.3.

[17] Daily and Dalton. 1994. Bankruptcy and Corporate Governance : The Impact of Board Composition and Structure. Academy of Management Journal. Vol. 37.

[18] Debarshi. Bhattacharyya. 2012. Financial Statement Analysis Noida, Doring Kimsdey. Licensees of Pearson Education in Sourth Asia

[19] Deviacita, Arieany, Tarmizi Achmad. 2012. Analisis Pengaruh Mekanisme Corporate Governance Terhadap Financial Distress. Diponegoro Journal Of Accounting. Vol. 1, No. 1.

[20] Elloumi and Gueyie. 2001. Financial Distress and Corporate Governance: An Empirical Analysis. The International Journal of Business in Society. Vol. 1 Issue 1, p.15- 23.

[21] Fitdini. 2009. Pengaruh Corporate Governance Terhadap Financial Distress. JKP XI. h. 236-247.

[22] Francis and Desai. 2005. Situational and Organizational Determinants of Turnaround. Management Decision. Vol. 43, Issue. 9.

[23] Hermalin dan M S.Weisbach. 2003. Board of Directors as an Endogenously Determined Institution: A Survey of the Economic Literatur. Economic Policy Review. p: 7-26.

[24] Indonesia Stock Exchange. 2014-2018. IDX Fact Book 2013-2018.(http://www.idx.co.id/)

[25] Jensen. 1993. The Modern Industrial Revolution, Exit and The Failure of Internal Control Systems. The Journal of Finance. Vol. 48, Issue 3.

[26] Jian and Wong. 2004. Earnings Management and Tunneling Through Related-Party Transactions, Evidence from Chinese Corporate Groups. Working paper, The Chinese University of Hong Kong and Nanyang Technological University.

[27] Jiang, M.C.Lee, and Yue, H. 2009. Tunneling Through Inter Corporate Loans, The China Experience. Journal of Financial Economics. Vol. 98. Research Collection School of Accountancy.

[28] Joseph Murphy. 2008, The Place of Leadership in Turnaround Schools, Journal of Educational Administration. Vol. 46, Issue 1, p. $74-98$. 
[29] Kahya, Emel, P. Theodossiou. 1999. Predicting Corporate Financial Distress, a Time Series CUSUM Methodology. Review of Quantitative Finance and Accounting. Boston, Kluwer Academic Publishers.

[30] Lipton and Lorsch. 1992. A Modest Proposal For Improved Corporate Governance. Business Lawyer No. 48.

[31] Liu, Q and Lu. 2007. Corporate Governance And Earnings Management In The Chinese Listed Companies, A Tunneling Perspective. Journal of Corporate Finance. Vol. 13, Issue 5.

[32] Makgeta. 2010. Turnaround Determinants of Distressed Firms Funded by The Industrial Development Corporation. Disertasi. University of Pretoria

[33] Mitton. 2002. A Cross Firm Analysis of the Impact of Corporate Governance on The East Asian Financial Crisis. Journal of Financial Economics.

[34] Platt and Platt. 2002. Predicting Financial Distres. Journal of Financial Service Professionals. Vol. 1, Issue. 56.

[35] Q. Liu and Z. Lu. 2007. Corporate Governance and Earnings Management in The Chinese Listed Companies, A Tunneling Perspective. Journal of Corporate Finance. Vol.13, p. 881-906.

[36] Schendel, Patton and Riggs. 1976. Corporate Turnaround Strategics, a Study of Profit Decline and Recovery. Journal of General Management. Vol. 3, Issue 3.

[37] Schuppe, Walter. 2005. Leading A Turnaround. The Secured Lender.

[38] Smith and Graves. 2005. Corporate Turnaround and Financial Distress. Managerial Auditing Journal. Vol. 20 , Issue 3.

[39] SU Dongwei, Xiong Jiacai. 2013. Tunneling and CEO Incentive Contract. Journal of Financial Research. School of Economics. Jinan University

[40] Widyasaputri. 2012. Analasis Mekanisme Corpporate Governance pada Perusahaan yang Mengalami Kondisi Financial Distress. Accounting Analysis Journal. Vol. 1, No. 2.

[41] Yermack. (1996). Higher Market Valuation of Companies with a Small Board of Directors. Journal of Financial Economics, No. 40.

[42] Yuliana, Dossugi. 2013. Analisis faktor-faktor yang mempengaruhi keberhasilan turnaround pada perusahaan yang mengalami financial distress. Jurnal Riset dan Konsep Manajemen, Vol. 8., No.2.

[43] Zong Jun, Xiao Lan. 2014. Corporate Governace and Financial Distress : Evidence From Chinese Listed Companies. The Chinese Economy Journal. Vol.39, Issue 5.

\section{AUTHOR'S BIOGRAPHIES}

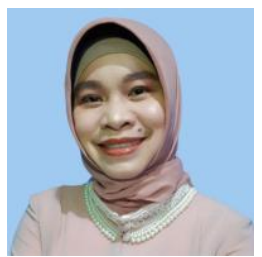

Dr. Eneng Sugihyanty, is a Finance, Accounting and Building Manager at the Building Management Kantor Taman A9, Mega Kuningan Jakarta. She earns Doctorate of Economics, majoring in Accounting from Pancasila University, Jakarta, Indonesia. Her research discusses the impact of corporate governance mechanism of manufacturing companies in Indonesia that experience financial distress on shareholder behavior in transferring assets and its implications for corporate turnaround.

Citation: Eneng Sugihyanty, et.al. “ Corporate Governance Mechanism on Tunneling Incentive and Financial Distress and Their Impact on Corporate Turnaround (Study on Manufacture Companies in Indonesia Stock Exchange on 2013-2018)" International Journal of Managerial Studies and Research (IJMSR), vol 8, no. 11, 2020, pp. 10-20. doi: https://doi.org/10.20431/2349-0349.0811002.

Copyright: (C) 2020 Authors. This is an open-access article distributed under the terms of the Creative Commons Attribution License, which permits unrestricted use, distribution, and reproduction in any medium, provided the original author and source are credited. 